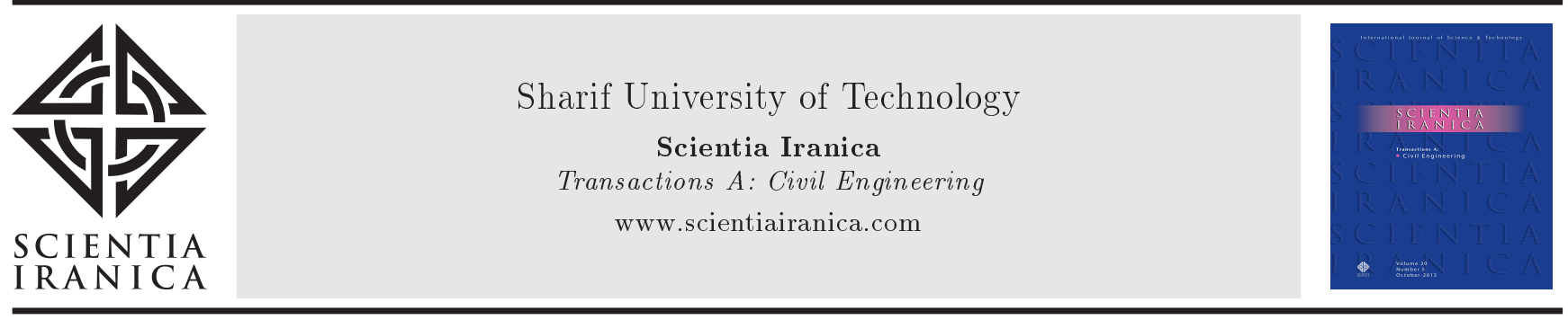

\title{
Study of land subsidence around the city of Shiraz
}

\author{
H. Rahnema ${ }^{a}$ and S. Mirassi ${ }^{\mathrm{b}, *}$ \\ a. Department of Civil and Environmental Engineering, Shiraz University of Technology, Shiraz, P.O. Box 7264102, Iran. \\ b. Department of Civil Engineering, Shahrekord Branch, Lordegan Center, Islamic Azad University, Shahrekord, P.O. Box 5224494, \\ Iran.
}

Received 4 August 2015; received in revised form 15 March 2015; accepted 15 September 2015

\author{
KEYWORDS \\ Land subsidence; \\ Fault; \\ Cracks; \\ Groundwater; \\ Fars.
}

\begin{abstract}
Land subsidence phenomenon due to human activities and natural factors has been observed in the plains of Fars province, which imposes heavy damage to agricultural lands, rural buildings, and historical monuments. In this paper, after identifying and determining rate of damage in Fars province, Marvdasht plain and its damaged villages have been chosen as the case study. The land subsidence map of Marvdasht and villages was presented by the data obtained from state of Groundwater, soil, and soil parameters. Also, the effects of faults, tectonic situation, dried qanat, occurred earthquakes in this area, and the observed fissured were taken into account. Generally, uncontrolled withdrawals from deep drilling wells caused subsidence and extended damage in other areas. Earthquakes intensified the damage to rural buildings and contributed to opening gaps. The altered subsidence identified in different parts of Marvdasht plain and the damage in rural areas along with the predictions made could represent the progressive damage of this phenomenon in the future. Finally, with respect to the climate, geology, land status, characteristic of soil layers, and regional potential, appropriate solutions for the land subsidence prevention and, consequently, reduction of the related damages were presented.
\end{abstract}

(C) 2016 Sharif University of Technology. All rights reserved.

\section{Introduction}

Land subsidence consists of collapse or settlement of the surface level that may occur due to some reasons such as the dissolution of subsurface formations, sediment compression [1], loading, drainage, vibration, subsurface mechanical erosion, shrinkage of clay soils, tectonic subsidence, and etc. [2]. Land subsidence, as a serious crisis, has been observed in several Iranian plains in recent years. By the continuation of drought and excess withdrawal of water resources, land subsidence and gaps have slowly extended and they can impose expensive financial and social costs on the government, gradually.

On a global scale, hazard of land subsidence due

\footnotetext{
*. Corresponding author. Tel.: +98 711 7264102;

Fax: +98 711 r264102

E-mail address: s.mirasi@sutech.ac.ir (S. Mirassi)
}

to dropping water levels reached its peak between 1950 and 1970, which coincided with industrialization and urbanization growth [3]. This phenomenon has been observed in many parts of the world such as northern Greece [4], northern Italy [5], China [6], Mexico [1], and Japan [7] in the past years. Hu et al. (2004) reported these phenomena in over 150 cities worldwide [8]. Maximum $120 \mathrm{~mm}$ annual subsidence due to water pumping was reported in the past 35 years in Bangkok, Thailand [9]. One of the most important regional land subsidences in the world has been reported in California, USA, in 1969 [10]. There was about $8 \mathrm{~m}$ settlement due to the uncontrolled exploitation of Groundwater for agricultural use. Until 1994, the amount of subsidence increased to $10 \mathrm{~m}$ due to $50 \mathrm{~m}$ water level dropping in this region [11].

In recent years, regional land subsidence related to the Groundwater level dropping has been reported in many parts of Iran, such as Ardakan plains of 
Yazd [12], Moin Abad in Varamin [13], and Shahryar in Tehran [14]. Also, subsidence along with the drop of Groundwater levels has been reported in many aquifers such as Sistan plain [15], Kashmar plain in Khorasan [16], and Mashhad plain. Other important plains can be mentioned as Mahyar region, in which a gap string with length of $10 \mathrm{~km}$ and width of 5 to $50 \mathrm{~cm}$ occurred during the past 10 years and it is opened wider $5 \mathrm{~cm}$ every year [17]. Another example of subsidence occurred in Rafsanjan plain, in which ground surface level subsided about $42 \mathrm{~cm}$ for every $10 \mathrm{~m}$ drop in Groundwater levels. For every $10 \mathrm{~m}$ drop in water level, the subsidence value of about $27 \mathrm{~cm}$ was reported in Sirjan region. Subsidence and sinkhole have been reported due to withdrawal of Groundwater in Kabotarang and Famenin plains, Hamedan province [18].

In this paper, the parameters related to land subsidence were investigated by observing and analyzing field and regional status data. First, the situation and location of plain and damaged villages were specified. Then, the geological data, the status of Groundwater level, type of soil layers, and depth of bedrock from the obtained logs of drilling were studied for the specified plain (i.e., damaged villages). And, also, other parameters needed for subsidence calculation were obtained from soil sampling and soil testing. The effects of faults on subsidence phenomenon and its damage on rural buildings were investigated considering earthquake occurrence in the past few years. Also, according to the site observations and residents' reports (first created cracks and fissures appeared near the qanat), the states of qanat, surface, and subsurface flows that were being dried were studied.

\section{Background}

\subsection{Regional and geological overview}

Marvdasht county is located in the Zagros fold belt. General trend of folding is along the North West to the South East in accordance with the Zagros fold. The lowest point of area with altitude of 1579 meters is located in the east (Raja Abad) and the highest point with altitude of 3000 meters from sea level is located in Dashtak. Major formations of this region are formed by carbonate formations such as Bangestan, Khami, and Torbor group so that the storage capacity and water transmission is becoming extremely high by developing process of breakup and karst phenomenon. Total area of this region is $3941 \mathrm{~m}^{2}$, of which $2452.5 \mathrm{~m}^{2}$ is plain. The direction of Groundwater movement in Marvdasht plain is from the north west highlands to the south east (Kherameh and then Bakhtegan Lake). The Kor River and its branches, including Maeen and Sivand, are permanent rivers in this plain that recharges the upstream part of the plain and drained the downstream

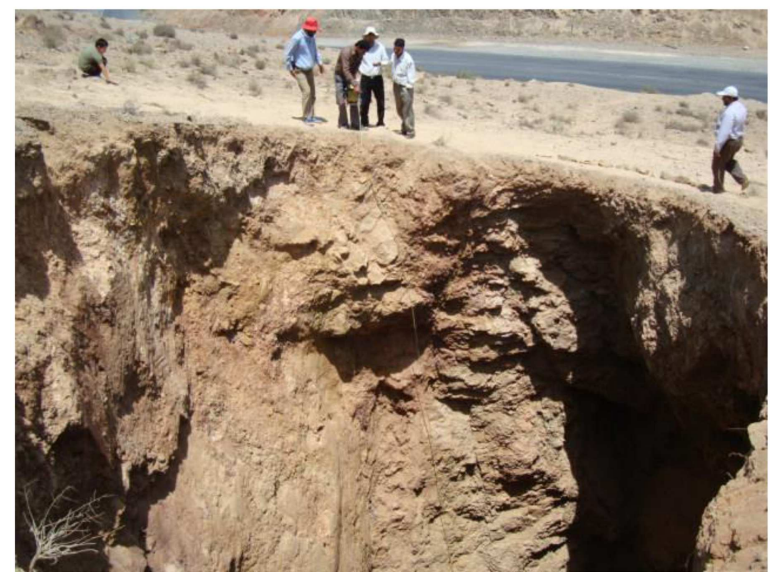

Figure 1. Creating sinkhole in Sormagh $(50 \mathrm{~m}$ diameter and $16 \mathrm{~m}$ depth).

part. The decreasing trend of Groundwater levels is continued to the center and southern margin of Marvdasht plain [19].

Land subsidence phenomenon has been reported in eight regions of Fars province: Marvdasht, Arzhan, Shiraz, NaghsheRostam, Darab, KuhSepid, sinkholes in Safashahr and Sormagh (Figure 1) [20]. Sinkholes in Sormagh were made as subsided ground in Jamal limestone formation. The ingredient of sinkhole's walls is mostly weathered siliceous limestone [21].

This county has a temperate climate; the mean annual maximum and minimum temperatures are 25.5 and $8.7^{\circ} \mathrm{C}$. This region is situated in the Zagros mountain range and potentially has a suitable fertile land, well pasture, and forest land [19].

Marvdasht plain is one of the most important plains that is located in $40 \mathrm{~km}$ north of Shiraz between the longitudes of $52^{\circ} 16^{\prime}$ and $53^{\circ} 30^{\prime}$ and the latitudes of $28^{\circ} 54^{\prime}$ and $30^{\circ} 26^{\prime}$ (Figure 2). The Groundwater level dropping and structural status of this region are the main causes of general settlement in the plain. Near the mountain hillside and places with variable soil layerings, especially under the villages and building areas, subsidence is more noticeable and considerable continuous cracks with depths of even more than $10 \mathrm{~m}$ and widths of more than $8 \mathrm{~cm}$. These cracks with their adjacent counterparts form an assumed strip with about $50 \mathrm{~m}$ width in the mountain hillside [21]. Shul village, Kamal- Abad, Zangi Abad, Ghasem Abad, and ancient monuments of Naqsh-e Rustam are located in this assumed strip (Figure 2) [22]. In this research, Shul village was completely investigated as a sample of the aforementioned areas.

Shul village is located in southwest of Hossein mountain hillside. The alluvial sediment of the village includes pebbles and cobblestones with some fine sediments in the range of clay size particles. The impairment and damage to rural houses have completely lost their utilization capability due to the 


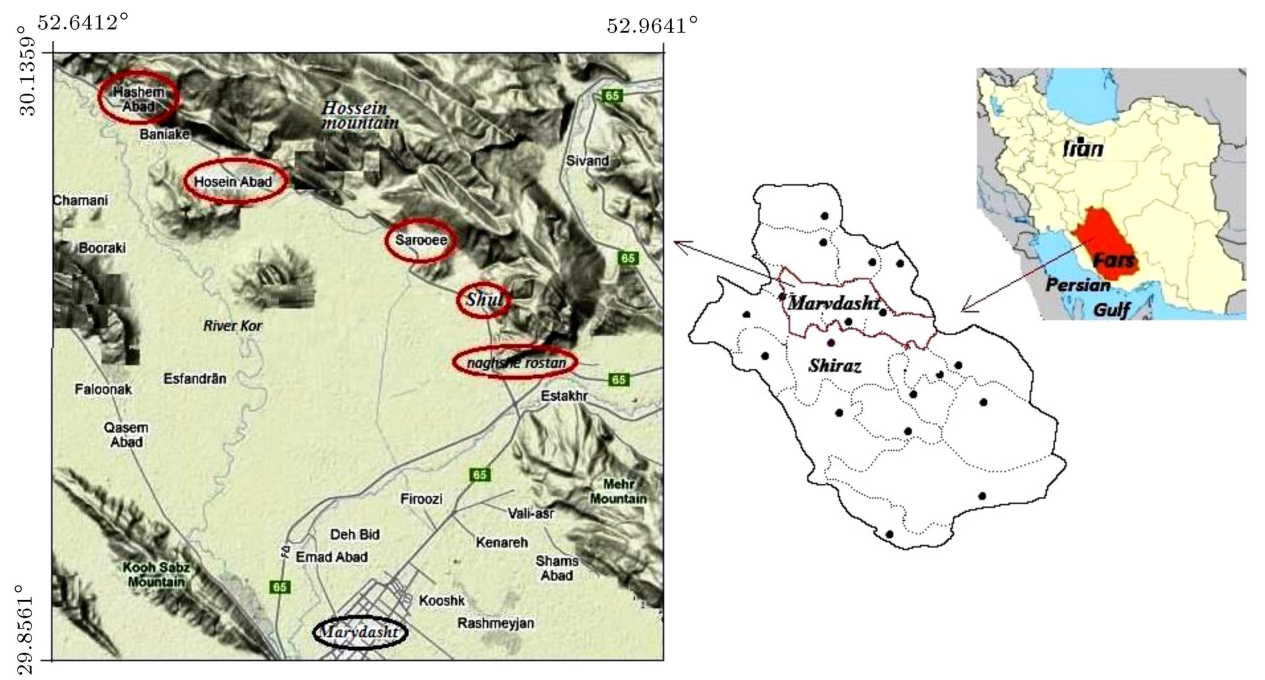

Figure 2. The location of damaged villages near the hillside mountain in Marvdasht plain, Fars province.

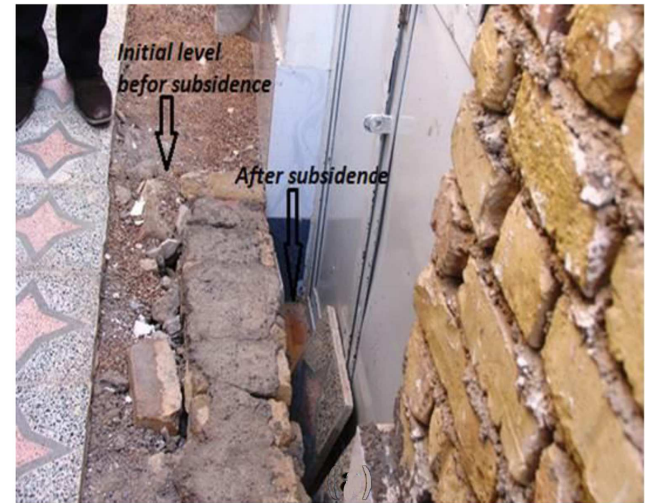

(a)

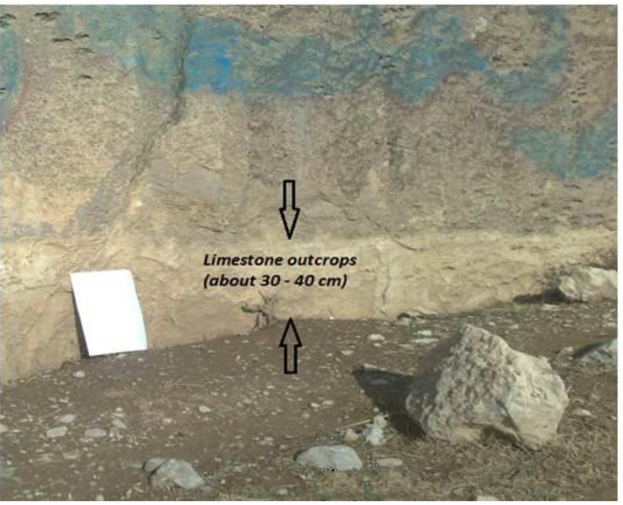

(b)

Figure 3. (a) Prolapse in rural houses $(20$ to $30 \mathrm{~cm}$ ). (b) The limestone or calcareous outcrops (Hossein mountain's bedrock) on the hillside of Hossein mountain near Shul village $(30-40 \mathrm{~cm})$.

appearance of cracks and fissures in walls, roofs, and floor.

Qualitatively, according to the field observations, $30 \mathrm{~cm}$ settlement can be considered for Shul village (Figure 3). However, the amount of building settlementaned mountains calcareous outcrops obtained (20 to $30 \mathrm{~cm}$ ) from field observation were more than the results of subsidence measurement (16 to $22 \mathrm{~cm}$ ) in northern part of Shul village [20]. This small difference indicates the probability of other factors which could affect land subsidence. The effect of qanats and faults on land subsidence is discussed below [23].

\subsection{Investigating rainfall status and Groundwater level}

According to the records of rainfall stations in Marvdasht plain, because of the reduction of precipitation from the water year 2005-06, the nation entered new drought duration. The reduction continued until 201011 and after that, slight increase in the rainfall amount was observed (Figure 4).

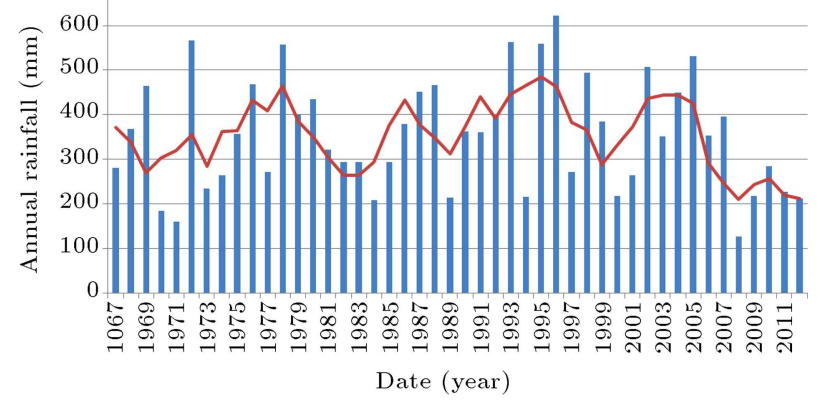

Figure 4. Annual rainfall curve.

By considering all the related hydrographs, the Groundwater level dropping initiated from 2005-06 and continued with a mild rate to $2008-09$. Then, the rate of water drop speeded up and continued until the water year 2011-12. It can be seen that there existed a 6year period of drought which was unprecedented in the past 50 years (Figure 5). The piezometer located in Shul village showed $23.02 \mathrm{~m}$ drop of water surface during 6 years period of drought from water year 2005- 


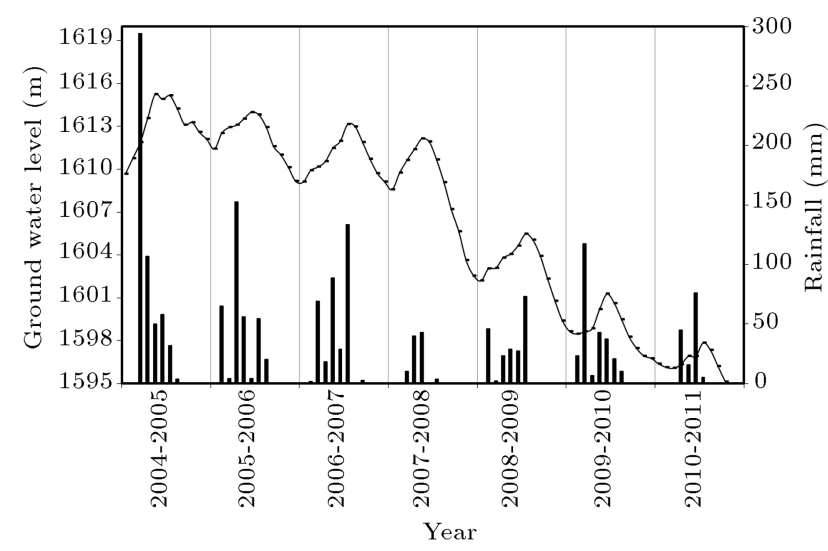

Figure 5. Hydrograph of Marvdasht plain between 2005 and 2011.

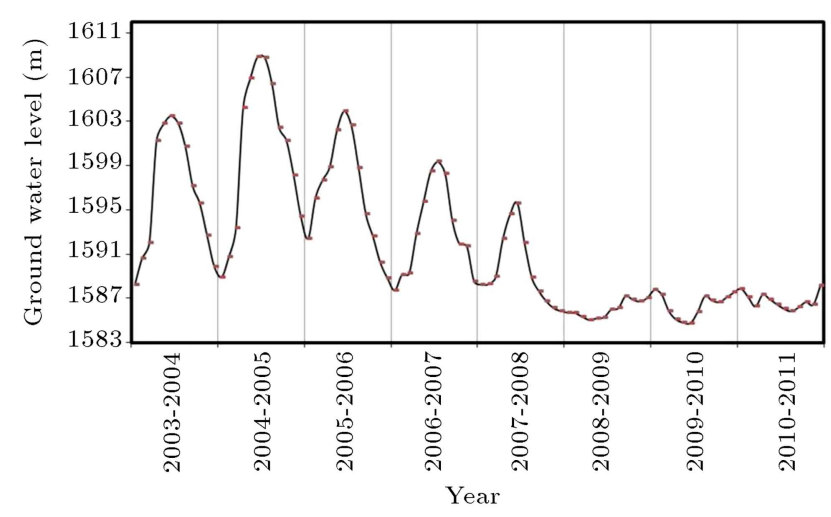

Figure 6. A typical graph of Groundwater withdrawal versus time at a piezometer at Shul village area. The measured mean water level drop is about $23.02 \mathrm{~m}$ in 6 years (2005-2011).

06 to $2010-11$ (Figure 6 ). It should be noted that the value of Groundwater level dropping is obtained from the differences between Groundwater levels in the first and the last years of drought period by considering the averages of Groundwater levels in February, March, April, and May for each year [20].

Regarding the start of drought in 2005-06, the maps of subsurface water contour lines in years 200506 and 2010-11 are shown in Figures 7 and 8 and also the amounts of subsurface water level falling between 2005-06 and 2010-11 in drought period of 6 years for all areas in Marvdasht plains are given in Figure 9. Subsurface water level in Shul village in 2005-06 years was approximately $1607.73 \mathrm{~m}$ that dropped to approximately $1586.30 \mathrm{~m}$ due to drought and reduced water levels in 2010-11 years. According to the contour lines, the highest subsurface water level falling in drought period was observed in Shul village and other villages located at the hillside of Hossein Mountain. The location of these villages in mountains hillside and geological formations with variable layers caused more vulnerability in these areas.

\section{Studying layers and bedrock profiles}

Soil type, depth of bedrock, and subsurface soil layering were determined using the data of drilled piezometers boreholes and drilling logs of agricultural wells (Figure 10). High depth is the advantage of using agricultural well logs which are also used to determine the depth of bedrock. Some of the wells were deleted due to lack of drilling log and not having enough information. And, finally, the data of 38 agricultural wells and 55 piezometers logs was used to identify soil layering and other parameters (Figure 11). Table 1 shows the characteristics obtained from agricultural wells in the area around of the Shul village.

In order to determine the cross sections of the soil, the locations of all wells are drawn on GIS, Google Earth, and AutoCAD Software. Then, changes in the depth of bedrock and soil layering are defined by considering hypothetical paths (i.e., path or section of A-A $\mathrm{A}^{\prime}$ ) among various wells (Figure 12). It should be noted that the depth of bedrock was estimated based on a limited number of wells (blue line) because of low depth of most wells and high thickness of alluvium layer. Based on the location of Shul village on the hillside; variable nature of soil layering, especially fine layers; and depth of bedrock, it was concluded that fine layer thickness in Shul village varied between 20 and $55 \mathrm{~m}$.

To investigate the mechanisms of cracks formation on ground surface, different patterns of ground deformation, depending on subsurface morphology and ground characteristics, are shown in Figure 13 [24]. The resulting racks are shown from differential settlements at locations of high gradient of sediment thickness (Figure 13(a) and (b)). The cracks formed in case of tensional forces locally developed after rotational movement of the upper slab around underground ridges. Shrinkage of the ground volume above the ridge induces tension cracks, i.e. opening of the ground ranging up to several tens of $\mathrm{cm}$ (Figure 13(c) and (d)) $[25,26]$.

\section{Subsidence estimation}

\subsection{Groundwater level dropping}

The thickness of clay layers and value of subsurface water level falling were considered as initial information for the calculation of land subsidence using the data from drilling logs of all the available piezometers in Marvdasht plain and logs of 38 agricultural wells. Water level falling occurs due to drought and immethodical withdrawal in the whole area in this plain that can be used as the result of odometer test showing that settlement and loading are in vertical direction and one-dimensional. Compaction capabilities of fine deposits were much more than sands and pebbles. The 


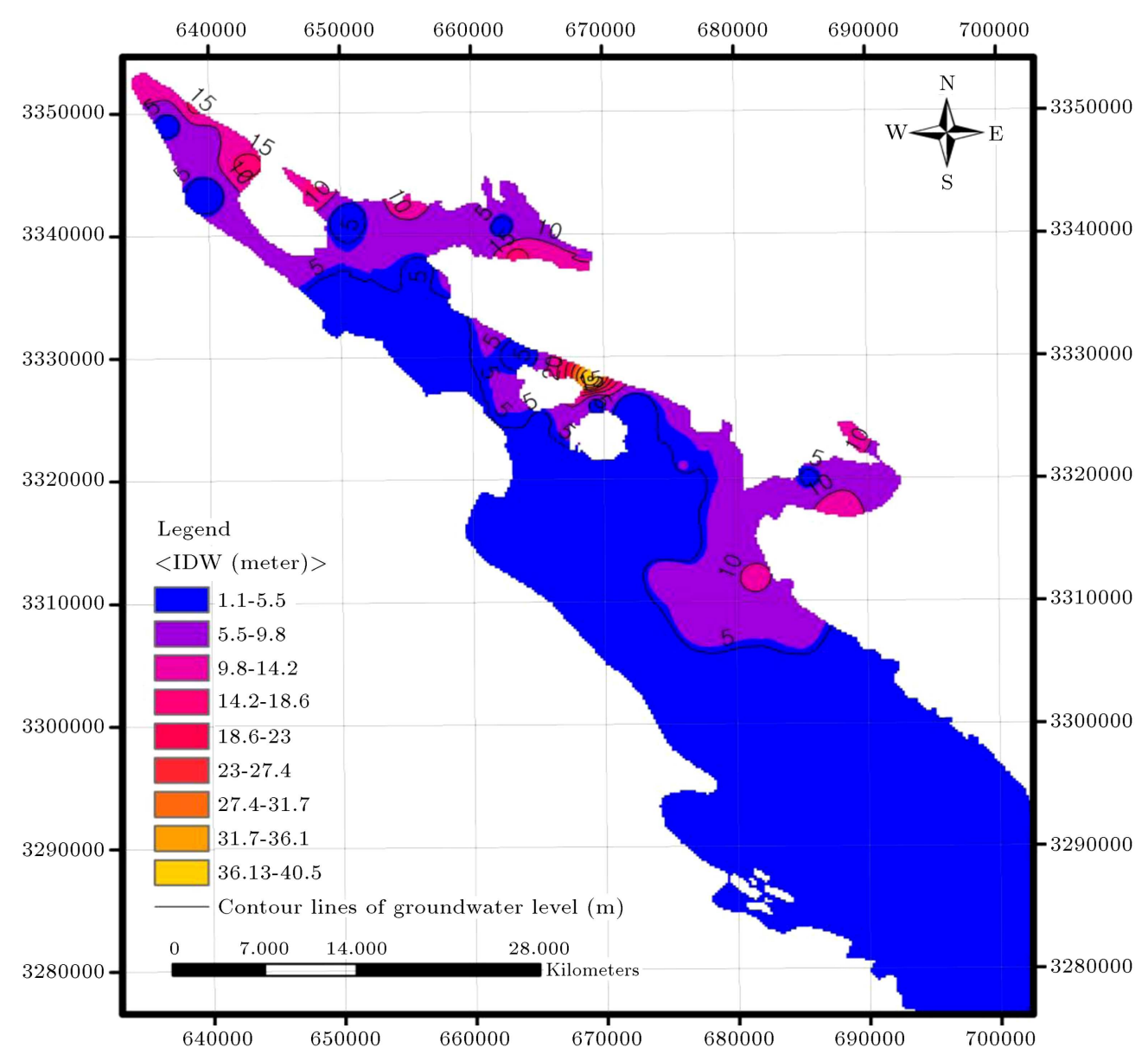

Figure 7. Subsurface water contour lines in Marvdasht plain (2005-06).

subsidence intensity occurred only where a thick clay deposit was available or layers of silt and clay were located in the saturated layers. In coarse soils (sand), due to high permeability, water was quickly carried on and consolidation of these soils did not receive much attention. In contrast, in fine soil (clay), due to low permeability and water absorption of clay minerals, water removal was done after a long time that made consolidation in fine soil very important and reduced pore water pressure. Assuming that changes in soil density due to water decline can be negligible, changes in total stress can be insignificant and effective stress in soil layers increases based on the principle of effective stress. For example, increase in the effective stress at point $\mathrm{A}$ due to decline in water levels in the sand layer to the height $\mathrm{H} 2$ was shown (Figure 14).

As an initial case, one can write:

$$
\begin{aligned}
\sigma_{V(\text { initial })}^{\prime}= & H_{1 \gamma \text { sand }}+H_{2}\left(\gamma_{\text {sat.sand }}-\gamma_{w}\right) \\
& +0.5 H_{3}\left(\gamma_{\text {sat.clay }-\gamma_{w}}\right)
\end{aligned}
$$

and as a final case:

$$
\sigma_{V(\text { final })}^{\prime}=H_{1 \gamma \text { sand }}+H_{2} \gamma_{\text {sand }}+0.5 H_{3}\left(\gamma_{\text {sat.clay }-\gamma_{w}}\right) \text {. }
$$

So, we have:

$$
\begin{aligned}
\Delta \sigma_{V}^{\prime}= & \left(H_{1}\left(\gamma_{\text {sand }}-\gamma_{w}\right)-H_{1}\left(\gamma_{\text {sand }}-\gamma_{w}\right)\right) \\
& +\left(H_{2} \gamma_{\text {sand }}-\left(\gamma_{\text {sat.sand }}-\gamma_{w}\right)\right) \\
& +\left(0.5 H_{3}\left(\gamma_{\text {sat.clay }}-\gamma_{w}\right)\right. \\
& \left.-0.5 H_{3}\left(\gamma_{\text {sat.clay }}-\gamma_{w}\right)\right) .
\end{aligned}
$$

And finally, the extra stress caused by the high amount of water decline was calculated as follows:

$$
\begin{aligned}
\Delta \sigma_{V}^{\prime} & =0+H_{2}\left(\gamma_{\text {sand }}-\gamma_{\text {sand }}^{\prime}\right)+0 \\
& =H_{2}\left(\gamma_{\text {sand }}-\gamma_{\text {sand }}^{\prime}\right) .
\end{aligned}
$$

It should be noted that with increase in the depth, compaction soil layers and elastic modulus of the soil increased, nonlinearly. Here, instead of using compression coefficient $\left(\mathrm{C}_{c}\right)$ as a constant, the coefficient of volume compressibility $\left(m_{v}\right)$ was used. The coefficient of volume compressibility was read with respect to the depth of each layer and the specific stress 


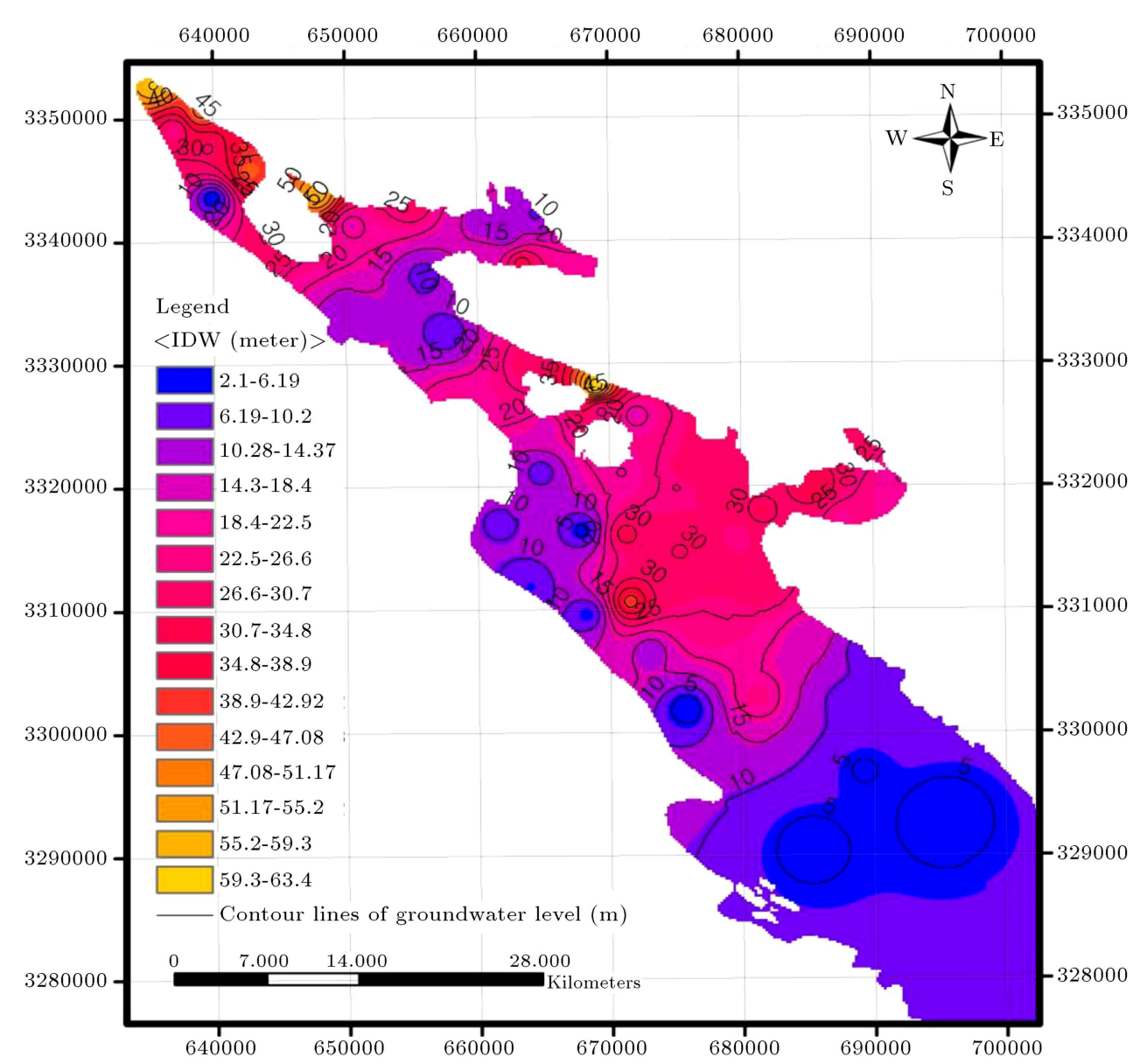

Figure 8. Subsurface water contour lines in Marvdasht plain (2010-2011).

endured by each layer from the result of oedometer test (Figure 15).

To exactly calculate subsidence, thickness of fine soil should be divided to small ranges between 2 and $5 \mathrm{~m}$; then, with respect to the coefficient of volume compressibility and stress rates of each layer, settelment should be considered in that layer.

$$
\begin{aligned}
& S_{c}=m_{v} z \Delta \sigma, \\
& \Delta \sigma=\Delta h\left(\gamma_{\text {sand }}-\gamma_{\text {sand }}^{\prime}\right),
\end{aligned}
$$

where:

$S_{c} \quad$ The amount of subsidence due to water decline $(\mathrm{m})$;

$z \quad$ Fine buried layer thickness $(\mathrm{m})$

$\Delta \sigma \quad$ Changes in effective pressure $\left(\mathrm{kPa}=\frac{\mathrm{kN}}{\mathrm{m}^{3}}\right)$;

$m_{v} \quad$ Coefficient of volume compressibility $\left(\frac{\mathrm{m}^{2}}{\mathrm{kN}}\right)$;

$\gamma_{w} \quad$ Unit weight of water $\left(\frac{\mathrm{kN}}{\mathrm{m}^{3}}\right)$;

$\gamma_{\text {sand }}^{\prime} \quad$ Immersion unit weight $\left(\frac{\mathrm{kN}}{\mathrm{m}^{3}}\right)$;

$\gamma_{\text {sand }} \quad$ Moist unit weight $\left(\frac{\mathrm{kN}}{\mathrm{m}^{3}}\right)$.

\subsection{Land Subsidence of Marvdasht plain due to Groundwater level Dropping}

After determining the decline rate of Groundwater levels in piezometers and soils layering based on the piezometers logs and also the required parameters from the collected samples, calculations of subsidence were performed. Subsidence maps of Marvdasht plain, due to water decline from 2005-06 to 2010-11, are presented in Figure 16. Based on the subsidence zoning map of Marvdasht plain, in Shul and its surrounding villages, the range of subsidence was obtained about 20 to $25 \mathrm{~cm}$. It can be said that this area with a blue color had the highest amount of subsidence and was more vulnerable. Its adjacent margins with softer blue were located in the second degree of subsidence that had the amount of subsidence at 15 to $20 \mathrm{~cm}$. Green color indicates elsewhere that had less subsidence of about 5 to $10 \mathrm{~cm}$ that was considerably low compared to other parts.

\subsection{Subsidence in Shul village and neighboring areas}

After analyses and interpretation of data from 70 irrigation wells with depths of between 70 and $280 \mathrm{~m}$, information of 38 wells was used, shown in Table 1. 


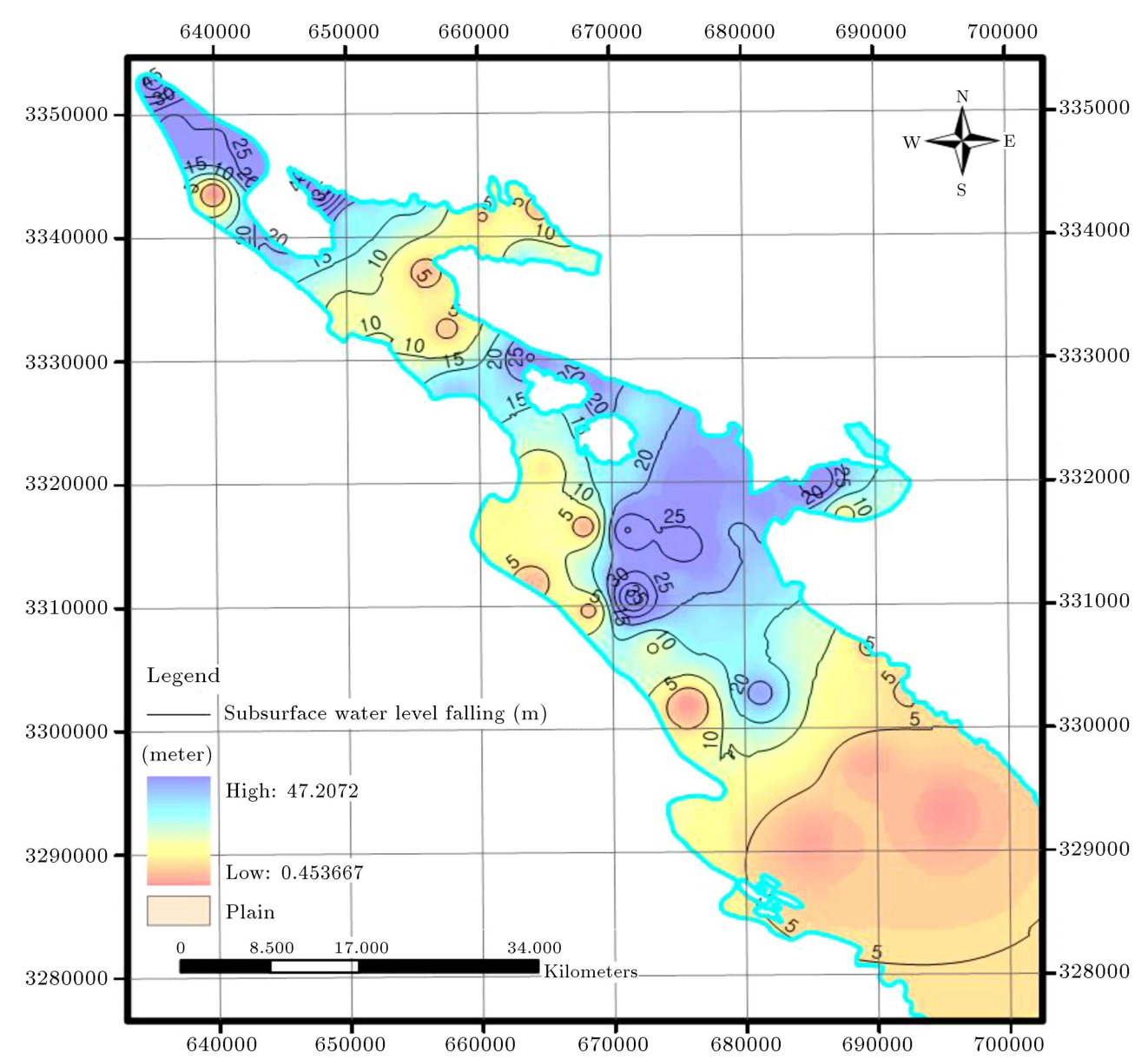

Figure 9. Subsurface water level falling between 2005-06 and 2010-11 in Marvdasht plain.

The amount of subsidence near the area of Shul village is calculated by using Eq. (4) with respect to the layering and thicknesses of clay layer and also falling amount of Groundwater levels that are obtained from Table 1, Figures 6 and 12. The amount of computed subsidence is presented in Figure 17. The thickness of alluvium and bedrock depth were determined to be accurate in this area and the amount of subsidence was calculated with sufficient accuracy. It was observed that the amount of subsidence in Shul village was about $16.5 \mathrm{~cm}$ and, getting away from the village, the amount of subsidence increased to about $22 \mathrm{~cm}$ due to increase in alluvium thickness; also, about $2 \mathrm{~km}$ away from the village, this amount reached $30 \mathrm{~cm}$.

\subsection{Effect of fine layers' thickness on subsidence}

As mentioned before and shown in Table 1 and Figure 6 , the soil thickness of fine layers near the Shul village is between the range of 20 to 55 meters and average of Groundwater level decline is about 21.5 meters. In the following graph, the effect of fine layer thickness is shown for constant water decline $(21.43 \mathrm{~m})$. It can be seen that the predicted amount of subsidence by using Eq. (4) in the fine layer with thickness of
$55 \mathrm{~m}$ was about $380 \mathrm{~mm}$ and the predicted amount of subsidence in fine layer with thickness of $35 \mathrm{~m}$ was about $200 \mathrm{~mm}$. Approximately, the predicted amount of subsidence in the layer with $55 \mathrm{~m}$ of thickness was more than 2 times of other layers with thickness of about 35 meters (Figure 18).

\section{Study of effect of faults and qanat on the subsidence}

\subsection{Seismic investigation}

Shul village was also located on Garmabad fault (revers slip fault) and the presence of this active fault caused anomalies in the sloped layering and inversion of the slope in the southwestern side of Hossein mountain anticline. The fault appeared as a rupture zone in the domain (Figure 19). By mapping the situation of created cracks and gaps into the desired region, based on their geographical locations, it was observed that the direction and vicinity of the cracks were along the fault, which indicated that the presence of fault accelerated creation of cracks in conjunction with the Groundwater level lowering [27].

The magnitudes of occurring earthquakes were almost close and less than 4 Richter during the past 

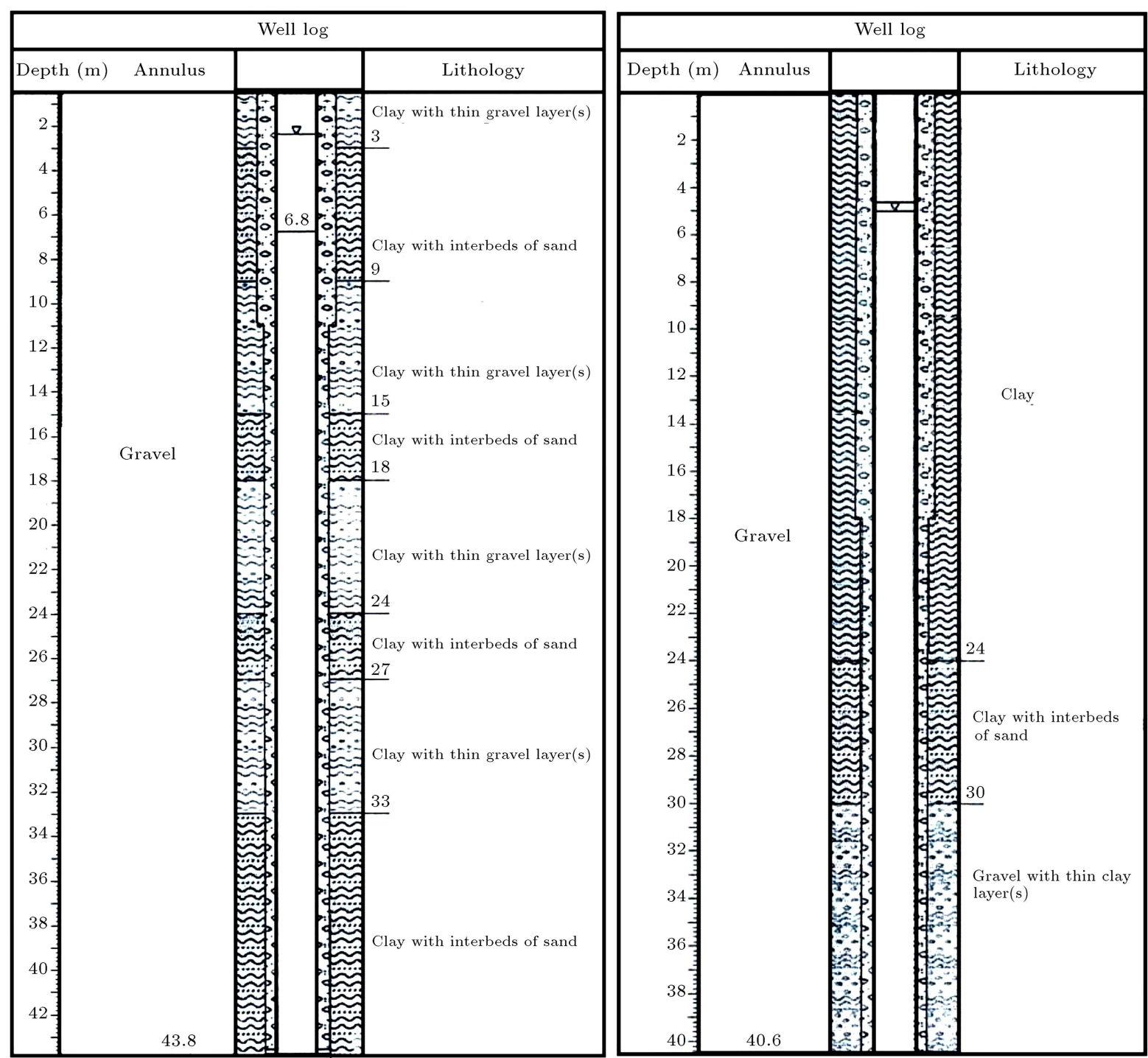

Figure 10. An example of drilling logs of piezometers.
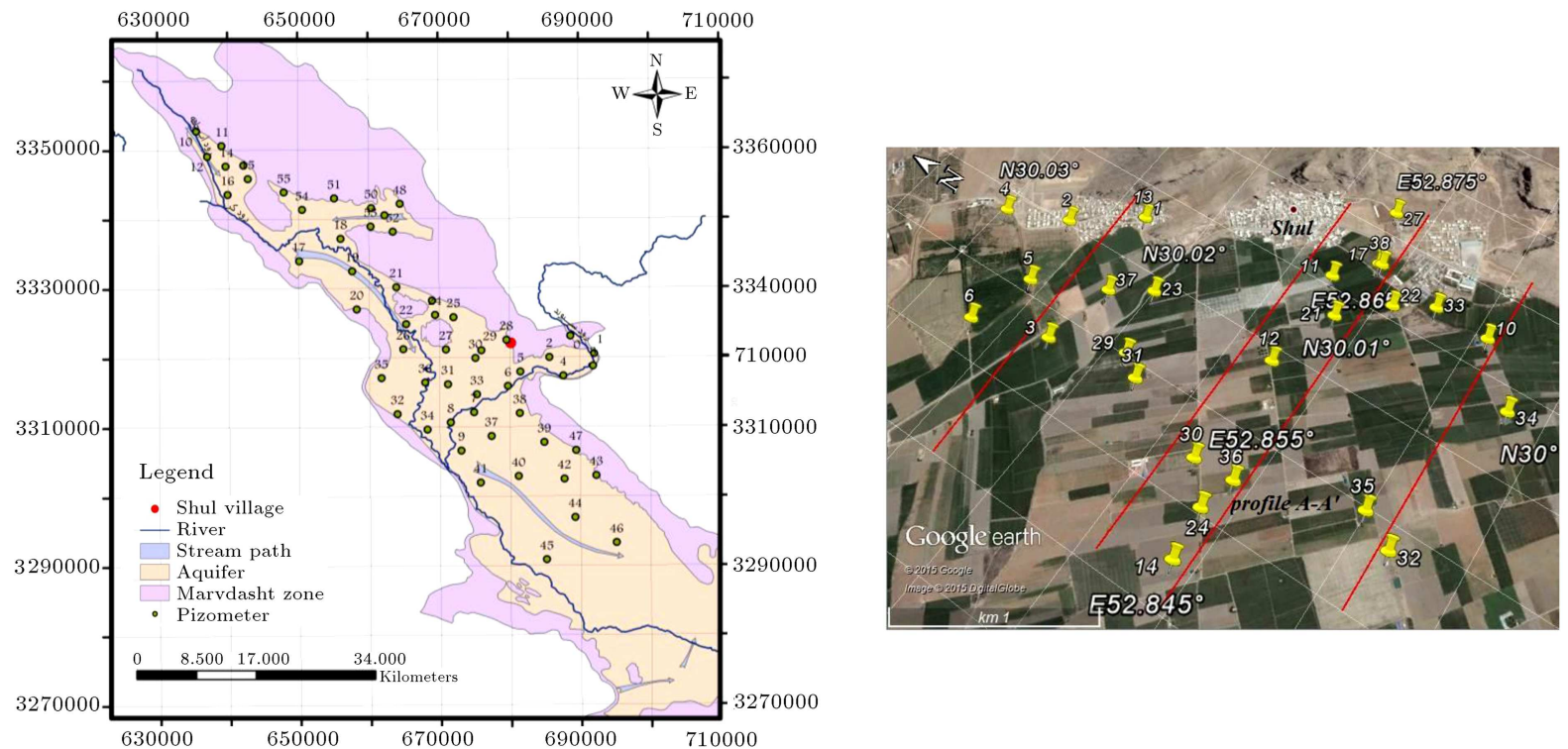

Figure 11. Location of piezometers in Marvdasht plain and distribution of agriculture wells around Shul village [20]. 
Table 1. Characteristics of agricultural wells around the Shul village.

\begin{tabular}{|c|c|c|c|c|c|c|c|c|}
\hline $\begin{array}{c}\text { Number of } \\
\text { wells }\end{array}$ & $\begin{array}{l}\text { Well } \\
\text { depth } \\
(\mathrm{m}) \\
\end{array}$ & $u t m_{x}$ & $u t m_{y}$ & $\begin{array}{c}\text { Sea } \\
7 \text { water } \\
\text { level } \\
\end{array}$ & $\begin{array}{c}\text { Water } \\
\text { level at } \\
\text { drilling time }\end{array}$ & $\begin{array}{c}\text { Bedrock } \\
\text { depth } \\
(\mathbf{m}) \\
\end{array}$ & $\begin{array}{c}\text { Clay } \\
\text { thickness }\end{array}$ & Formation \\
\hline 1 & 75 & 679575 & 3322780 & 1632 & 8 & - & 23 & Alluvial \\
\hline 2 & 120 & 679312 & 3323141 & 1635 & 10 & - & 48 & Alluvial \\
\hline 3 & 80 & 678673 & 3322728 & 1632 & 10 & 100 & 41.4 & Alluvial \\
\hline 4 & 100 & 679167 & 3323501 & 1635 & 6 & - & 35 & Alluvial \\
\hline 5 & 70 & 678889 & 3323059 & 1635 & 6 & - & 36 & Alluvial \\
\hline 6 & 150 & 678528 & 3323169 & 1634 & 10 & - & 26 & Alluvial \\
\hline 8 & 150 & 678648 & 33221280 & 1638 & 10 & - & 29.25 & Alluvial \\
\hline 10 & 100 & 679996 & 3320720 & 1635 & 10 & - & 26.25 & Alluvial \\
\hline 11 & 190 & 679857 & 3321645 & 1638 & 10 & - & 37.5 & Alluvial \\
\hline 12 & 150 & 679236 & 3321629 & 1644 & 10 & - & 18.75 & Alluvial \\
\hline 13 & 74 & 679575 & 3322780 & 1632 & 6 & 70 & 22.5 & Alluvial \\
\hline 14 & 200 & 678118 & 3321428 & 1635 & 10 & 147 & 32.25 & Alluvial \\
\hline 17 & 83 & 680070 & 3321465 & 1634 & 6 & - & 32.25 & Alluvial \\
\hline 21 & 150 & 679651 & 3321496 & 1636 & 10 & - & 33.75 & Alluvial \\
\hline 22 & 150 & 679883 & 3321260 & 1644 & 10 & - & 45 & Alluvial \\
\hline 23 & 150 & 679218 & 3322426 & 1634 & 10 & 97 & 41.25 & Alluvial \\
\hline 24 & 90 & 678392 & 3321468 & 1635 & 10 & & 55 & Alluvial \\
\hline 27 & 79 & 680420 & 3321560 & 1649 & 10 & 79 & 27.75 & Alluvial \\
\hline 29 & 160 & 678836 & 3322315 & 1633 & 10 & - & 24.75 & Alluvial \\
\hline 30 & 96 & 678576 & 3321650 & 1634 & 10 & - & 37.5 & Alluvial \\
\hline 31 & 150 & 678750 & 3322180 & 1632 & 6 & - & 51 & Alluvial \\
\hline 32 & 138 & 678728 & 3320580 & 1634 & 6 & 138 & 41.25 & Alluvial \\
\hline 33 & 75 & 680007 & 3321049 & 1633 & 6 & & 22.5 & Alluvial \\
\hline 34 & 70 & 679680 & 3320432 & 1635 & 10 & - & 52.5 & Alluvial \\
\hline 35 & 100 & 678833 & 3320777 & 1635 & 10 & 100 & 43.5 & Alluvial \\
\hline 36 & 138 & 678592 & 3321414 & 1632 & 10 & 138 & 55 & Alluvial \\
\hline 37 & 85 & 679082 & 3322647 & 1633 & 10 & - & 45 & Alluvial \\
\hline 38 & 180 & 680076 & 3321448 & 1639 & 6 & 160 & 30 & Alluvial \\
\hline
\end{tabular}

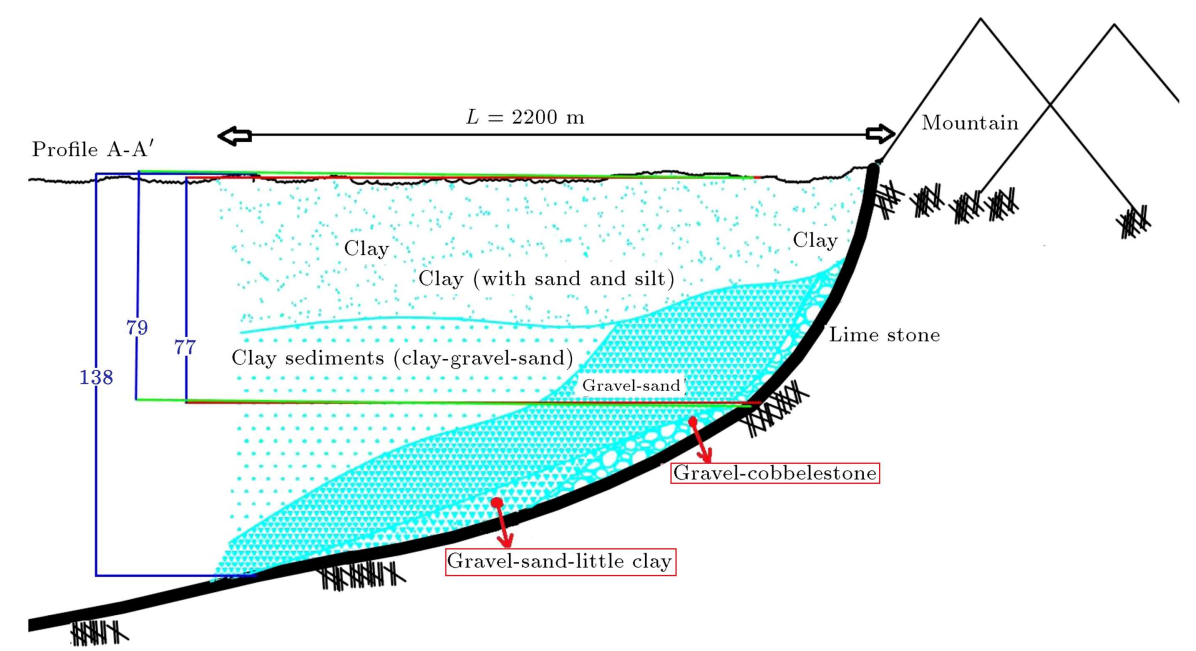

Figure 12. Geological cross-section along profile A-A' estimated from well data near the investigated sites (meter). 


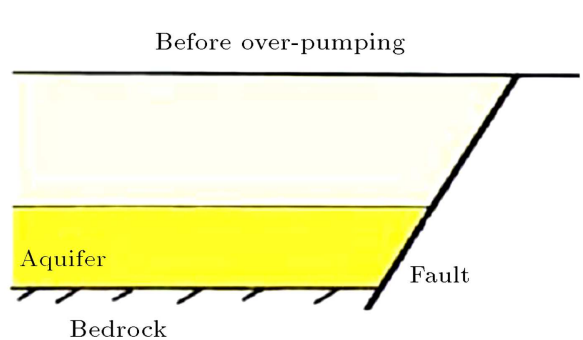

(a)

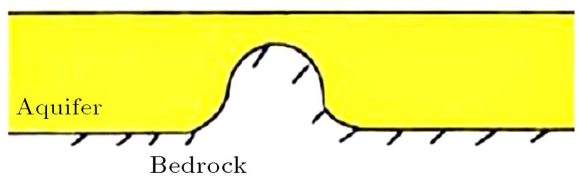

(c)

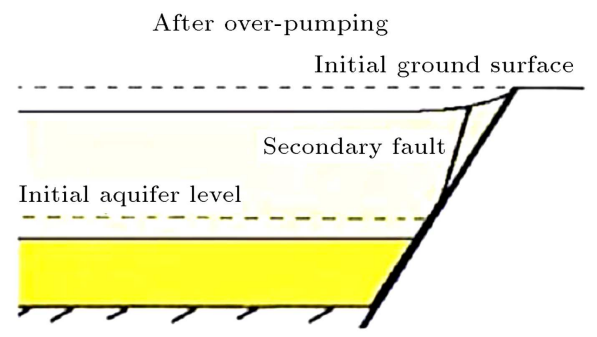

(b)

After over-pumping

Initial ground surface

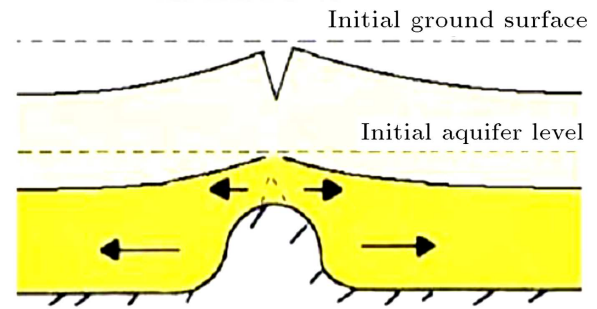

(d)

Figure 13. Cartoons to explain formation of: (a) and (b) fissures (secondary faults), (c) and (d) tensional cracks above a subsurface ridge [26].

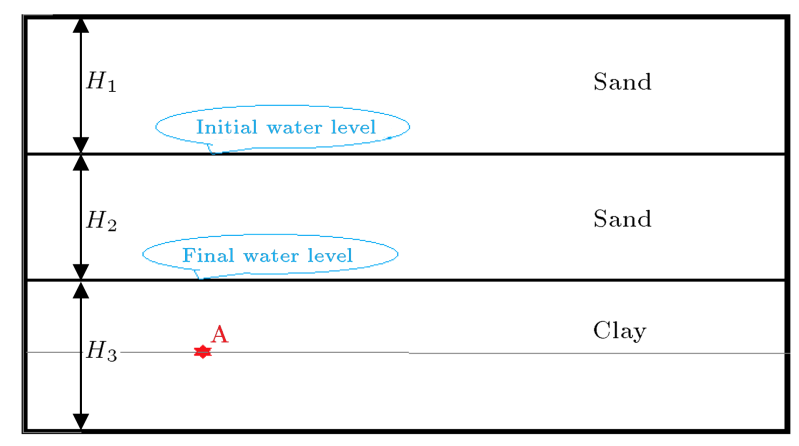

Figure 14. Increasing the effective stress due to decline of water levels.

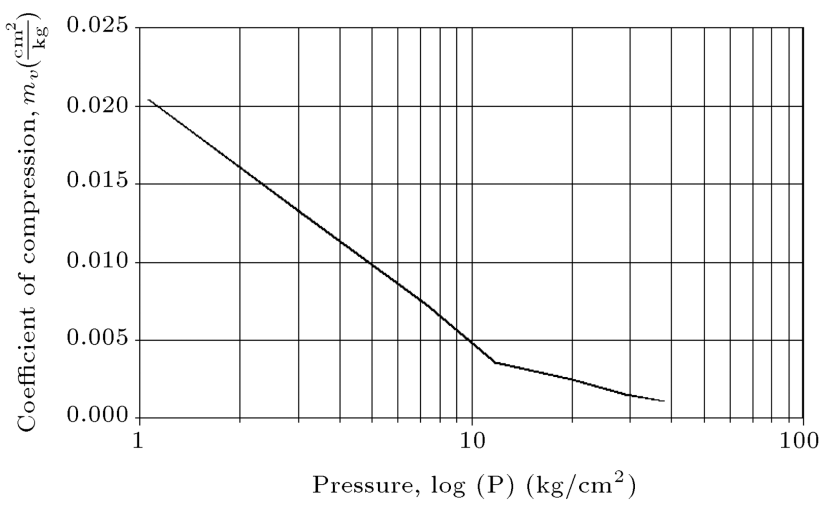

Figure 15. Variations of volume compressibility coefficient versus increase in stress (in logarithmic space).

30 years. Two to three earthquakes have occurred per year. According to the report of the local residents, in the past few years (4 years ago), relatively severe earthquakes accelerated the opening of cracks and fissures, of which the effects were observed in some buildings. So, the coincidence of cracked zone with the fault vicinity and the residents' reports based on observing cracks and fissures on buildings after the earthquake could lead to the conclusion that the existing fault accelerated subsidence in this area and exacerbated damage to rural buildings (Figure 19).

\subsection{Effect of qanat and subsurface streams on subsidence}

Several thousand years ago, ancient Persians invented a new irrigation system called qanat, which consisted of a water supply system to transfer under groundwater to the ground surface by using only the gravitational potential energy of Groundwater and without using a mechanical system. Generally, qanat consists of an opening main well (mother well) and canal-like underground tunnels and also several vertical wells that make linked underground canal at specific intervals with the surface. Immethodical Groundwater withdrawal through the drilled wells causes drops at Groundwater level and qanat gets dry and abandoned. If the canal of qanat is placed at low depth from ground surface, gradual loss of qanat roof leads to the subsidence of ground surface. Delayed exploitation of Imam Khomeini International Airport of Iran for a long time or land subsidence in Iranian Artillery Subway Station are examples of land subsidence that are related to qanat [28].

Field observations, the location of cracks, and localizing the existing qanat determined the location of cracks and fissures on the northern border of Shul village as consistent with the location of old qanat and subsurface streams (Figure 20). According to the available reports, initial surface cracks started to 


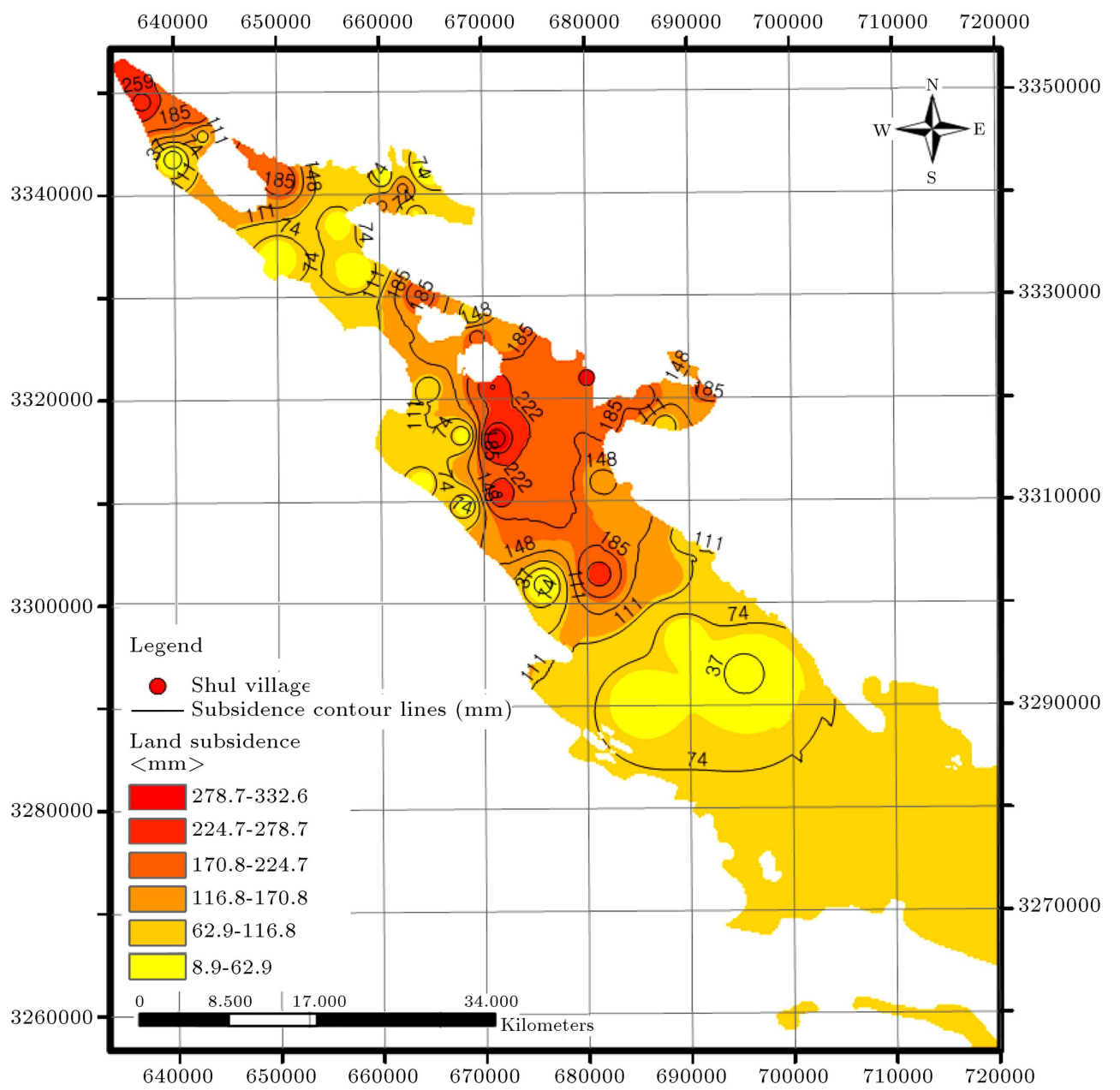

Figure 16. Contour line of land subsidence amount in Marvdasht plain.

appear when qanat and surface stream dried. It can be concluded that the initial cause of these cracks can be the drop in Groundwater levels and dried qanat and surface streams. Cracks and gaps in this area emerged due to the difference in subsidence between locations of qanat canals, in which water had already flowed, and the surrounding area with no cavity and change in the underlying layers. Comprehensive and complete studies with regard to cracks and fissures created in other places and other qanat series within the studied area and its adjacent areas demonstrated that this consistency was only in a limited number of places; and in some other places, such as Shul village, there were very large cracks which caused many failures, but there were no qanats.

\section{Proposed strategies to prevent and stop damage}

Based on general analysis of the data obtained from studies and site investigations, the most important factors which caused land subsidence in Marvdasht plain and damage to rural buildings were water level dropping due to excessive exploitation of water resources, the decrease of precipitation during the studied time, and presence of thick clay. The coincidence of cracked zone with the fault vicinity, dried qanats, and existence of alluvial terraces were other weak points of the investigated region compared to other areas. These resulted in the generation of deep cracks (more than $10 \mathrm{~m} \mathrm{depth}$ ) and wide openings (more than $8 \mathrm{~cm}$ width). Qanats have affected appearance of cracks and gaps and have created susceptible areas to develop cracks and gaps. In other words, cracks and gaps can be seen sooner and better in qanat areas caused by a drop in Groundwater levels and other factors.

However, by the appearance of extended cracks in the roofs, floors, and walls of such structures due to land subsidence, their building workability is lost and a critical situation, financial problems, and residential costs may be imposed in present and future. Basic strategies for preventing and stopping damage of subsidence phenomenon in these areas according to the agricultural situation in the region, climate, geology, land farm situation and layered soils, potential of these areas, and many other factors are as follow: 


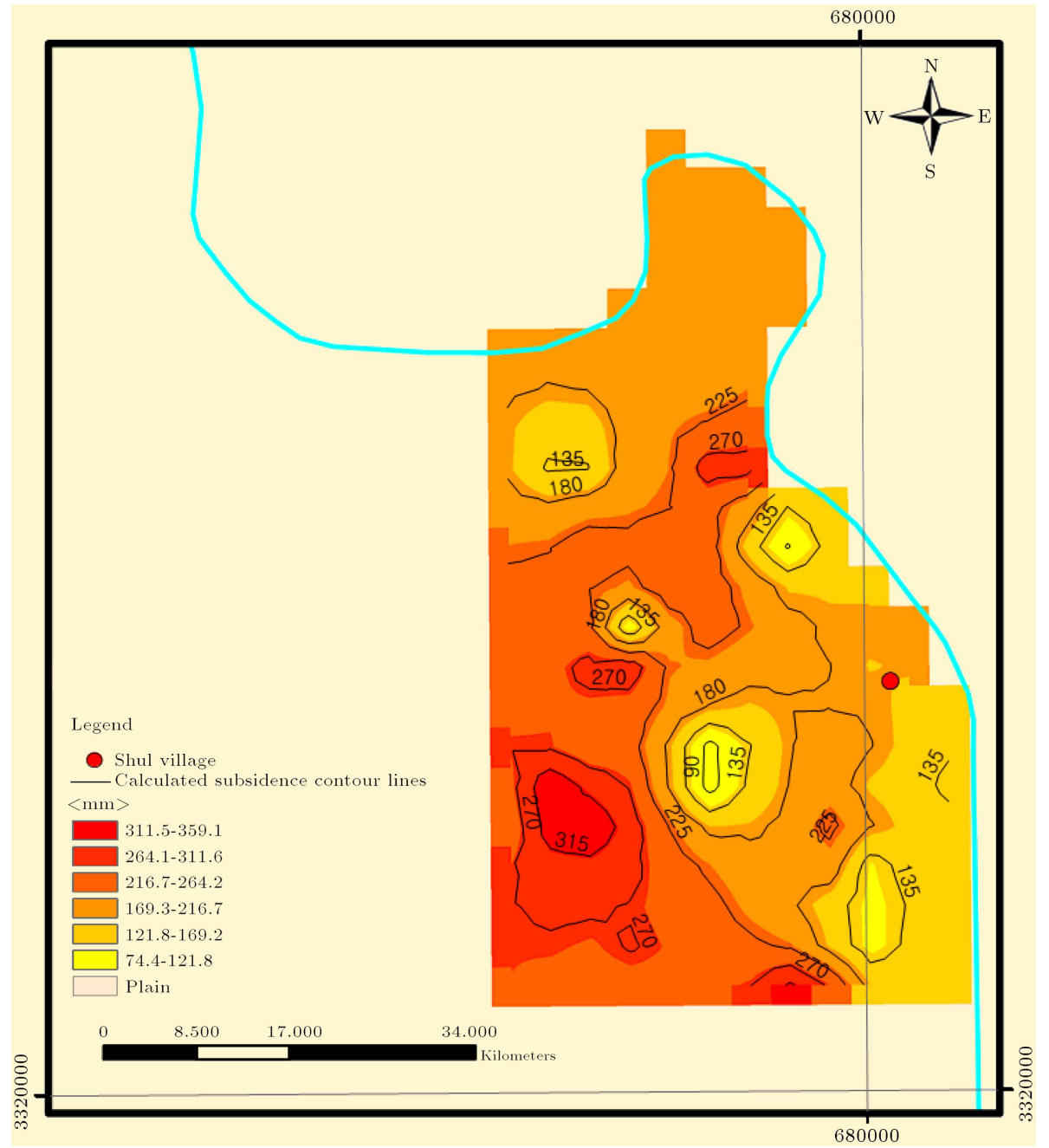

Figure 17. Amount of calculated subsidence near Shul village due to Groundwater level decline (mm).

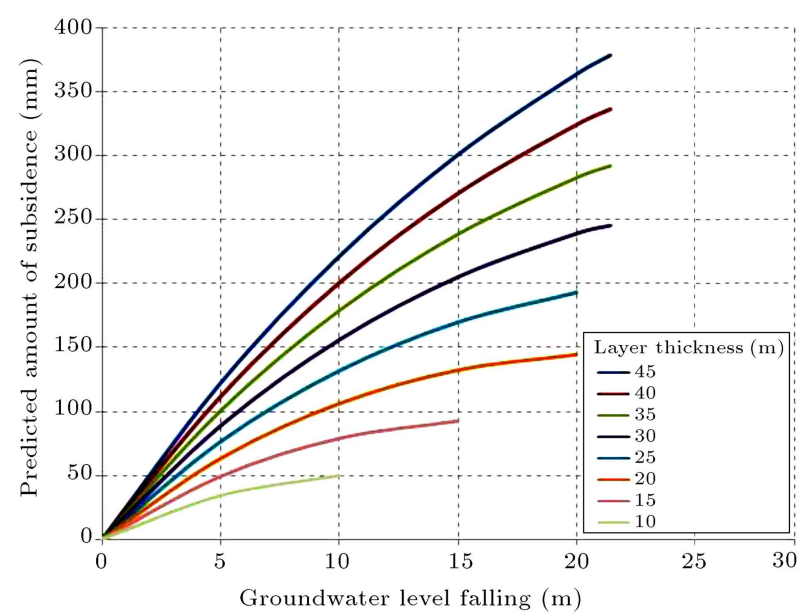

Figure 18. Predicted amount of layer subsidence by different thicknesses in the range of Shul village.

- Reducing exploitation of under groundwater resources for agricultural and industrial uses;

- Controlling drilling depth and utilization of licensed wells, blocking illegal wells;

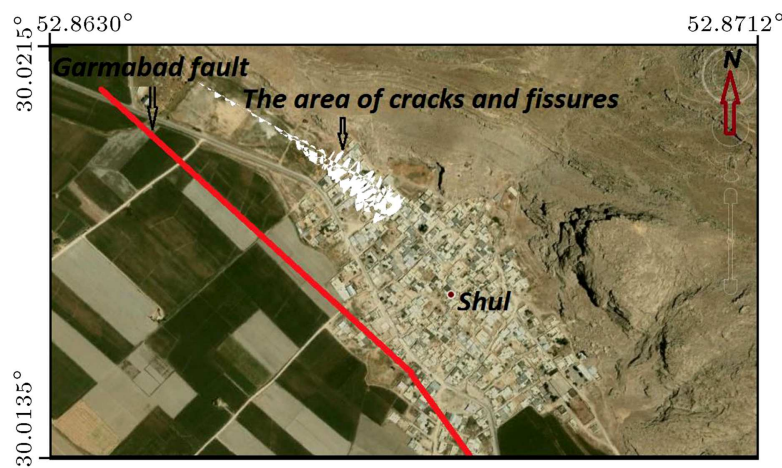

Figure 19. Area of cracks and fissures in Shul village $[22,27]$.

- Changing patterns of cultivation and using modern irrigation methods such as irrigation under pressure, drop, rainy, and green house cultivation;

- Preventing construction of buildings in the area of gaps and cracks (rural areas);

- Informing farmers of the effects of uncontrolled removal of Groundwater and its consequences; 


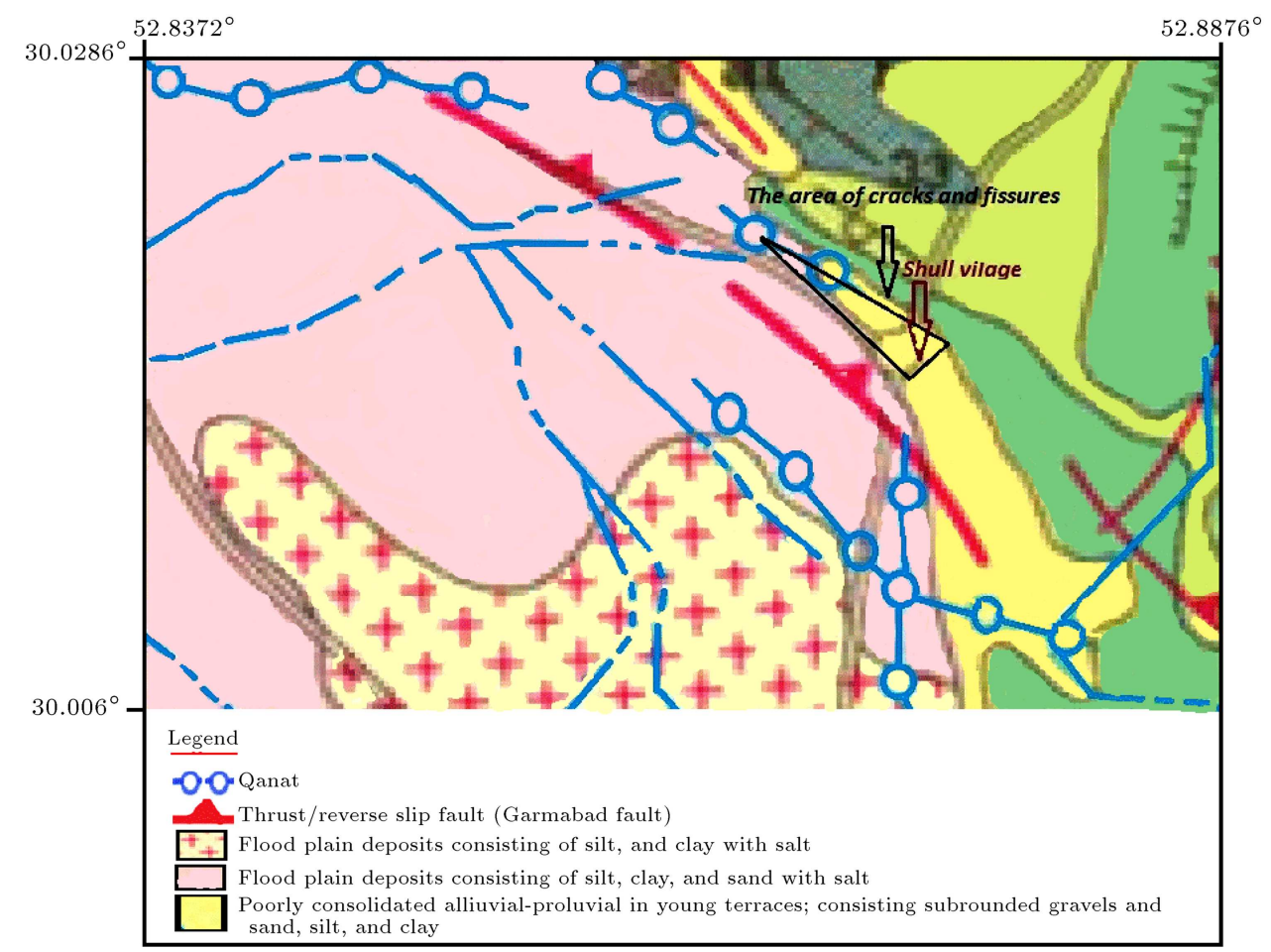

Figure 20. Geological map (situation of qanat and subsurface canal) [22,27].

- Regarding the increasing population and rising demand for using under groundwater resources, it is better to invest in the industry and reduce pressure on under groundwater resources;

- Providing services to investors for the construction and industrial projects with respect to the potential of Marvdasht city;

- Studying and determining location of qanat system before building the construction.

\section{Conclusion}

The land subsidence of Marvdasht and Shul village was studied. The required data was collected from the state of Groundwater, soil parameters, the existing faults, dried qanat, occurred earthquakes, and the observed fissures. Studies of the fault location with respect to the direction and vicinity of the cracks have proved that the presence of fault accelerated creation of cracks in conjunction with the Groundwater level dropping and exacerbated damage to rural buildings. The qanats were found not to have the essential effect on subsidence; but in some places, they were recognized to have some limited effect on land subsidence. The main cause of the land subsidence in the high thickness of land alluvial is discovered to be the falling of Groundwater level due to the excessive exploitation of water resources and the decrease in precipitation. In this way, the accelerating factor of the Groundwater drawdown should be eliminated. Therefore, some feasible and practical methods are proposed to control water drawdown. As a practical strategy to stop and control ground subsidence, some solutions such as reducing exploitation of under groundwater, preventing dipper drilling of wells, changing patterns of cultivation, enforcing regulations for construction in these areas, training the farmers, and changing investment policies in industry are proposed.

\section{References}

1. Pacheco, J., Arzate, J., Rojas, E., Arroyo, M., Yutsis, V. and Ochoa, G. "Delimitation of ground failure zones due to land subsidence using gravity data and finite element modeling in the Queretaro valley, Mexico", Engineering Geology, 84(3), pp. 143-160 ( 2006).

2. NRC, Mitigating Losses from Land Subsidence in the United States, Washington, D.C., National Academy Press, p. 58 (1991).

3. Waltham, A.C., Ground Subsidence, (Blackie \& Son Limites), p. 202 (1989).

4. Stiros, S.C. "Subsidence of the Thessaloniki (northern Greece) coastal plain, 1960-1999", Engineering Geology, 61(4), pp. 243-256 (2001).

5. Carminati, E. and Martinelli, G. "Subsidence rates in the Po plain, northern Italy: The relative impact of natural and anthropogenic causation", Engineering Geology, 66, pp. 241-255 (2002).

6. Hu, R.L., Wang, S.J., Lee, C.F. and Li, M.L. "Characteristics and trends of land subsidence in Tanggu, Tianjin, China", Bulletin of Engineering Geology and the Environment, 61, pp. 213-225 (2002). 
7. Zhou, G.Y. and Esaki, T.J. "GIS based spatial and predication system development for regional land subsidence hazard mitigation", Environmental Geology, 44, pp. 665-678 (2003).

8. Hu, R.L., Yue, Z.Q., Wang, L.C. and Wang, S.J. "Review on current status and challenging issues of and subsidence in China", Engineering Geology, 76, pp. 65-77 (2004).

9. Phien-Wej, N., Giao, P.H. and Nutalaya, P. "Land subsidence in Bangkok, Thailand", Engineering Geology, 82(4), pp. 187-201 (2006).

10. Poland, J.F. "The occurrence and control of land subsidence due to Groundwater withdrawal with special reference to the San Joaquin and Santa Clara valleys, California", Ph.D. Dissertation, Stanford University, Palo Alto, California (1981).

11. Larson. K.J., Basagaoglu, H. and Marino, M.A. "Prediction of optimal safe Groundwater yield and land Subsidence in the Los Banos-Kettleman city area, California", Using a Calibrated Numerical Simulation Model, Journal of Hydrology, 242, pp. 79-102 (2001).

12. Alemi, A. "Investigating the causes of subsidence in Yazd plain", Articles Collections of the Third International Conference of Soil Mechanics and Geotechnical, Tehran, Iran, pp. 434-429 (2002).

13. Shemshaki, A. and Entezam Soltani, A. "Mechanism the reasons of cracks formation in Moeinabad area, Varamin", Fourth Conference on Engineering Geology and the Environment, Tehran, Iran, pp. 191-178 (2005).

14. Alipour, S.M., Motagh, M., Sharifi, and Walter, T.R. "Satellite radar interferometry time series analysis of land subsidence caused by Groundwater overexploitation in Tehran, Iran", In Geophysical Research Abstracts, 10 (2008).

15. Rahnamarad, J. and Firozan, M. "Studying Effects of periodic drought and erosion phenomenon on buildings in Sistan plain", Journal of Geotechnical and Strength of Materials, 88, pp. 39-30 (2002).

16. Lashkaripour, G. "Study of the formation of cracks and land subsidence reasons in west plains of Kashmar", Geological Studies, 1(1), pp. 95-111 (2009).

17. Ajalloeian, R. and Bahadanor, B. "The relationship between Groundwater variations and landslides, subsidence and cracks in ground surface", Proceedings of the Second Conference of Intensive Geological Society of Iran, pp. 35-27 (1999).

18. Aghda, F., Nakhaei, S.M., Baytollahi, M. and Aliyari, A. "Studying mechanism of sinkhole formation in central plains of Hamadan", Proceedings of the Second Conference on Engineering Geology and the Environment, II, pp. 701-691 (2001).

19. Research Report of Marvdasht-Kherameh Area, Regional Water Company of Fars province, Iran (2010).
20. Rahnema, H. and Mirassi, S. "Crisis management concerning underground water falling and land subsidence occurrence in the plains of Iran", Advances in Environmental Biology, 8(5), pp. 1453-1465 (2014).

21. Geological survey of Shiraz, Iran, "www.ngdir.ir" (2010).

22. Rahnema, H. and Mirassi, S. "Seismic study of land subsidence and vulnerability of rural buildings by using geophysics methods, near Shiraz city", International Research Journal of Applied and Basic Sciences, 7(11), pp. 718-724 (2013).

23. Mirassi, S. "Study of land subsidence phenomenon with considering all affecting factors and its effects on rural buildings in Marvdasht plain, Fars", MSc Thesis, Shiraz University of Technology (2012).

24. Kontogianni, V., Pytharouli, S. and Stiros, S. "Ground subsidence, Quaternary faults and vulnerability of utilities and transportation networks in Thessaly, Greece", Environ Geol, 52, pp. 1085-1095 (2007).

25. Bouwer, H. "Land subsidence and cracking due to Groundwater depletion", Ground Water, 15(5), pp. 358-364 (1977).

26. Jachens, R. and Holzer, T. "Differential compaction mechanism for earth fissures near Casa Grande, Arizona", Geological Society of America, Bulletin, 93(10), pp. 998-1012 (1982).

27. Rahnema, H. and Mirassi, S. "Seismic and geotechnical study of land subsidence and vulnerability of rural buildings", International Journal of Geosciences, 3, pp. 878-884 (2012).

28. Hafezi Moghadam, N., Ghafoori, M. and Ghezi, A. "The problem of ancient qanat in Mashhad city", Fifth Conference on Geological and Environmental of Iran (2008).

\section{Biographies}

Hossein Rahnema received his $\mathrm{PhD}$ degree in Geotechnical Engineering from Shiraz University, Shiraz, Iran. His research interests include geotechnical earthquake engineering, pavement design, geoenvironmental, and also space structures. He is currently an Assistant Professor in the School of Civil and Environmental Engineering at Shiraz University of Technology, Shiraz, Iran.

Sohrab Mirassi obtained his MS degree in Geotechnical Engineering from Shiraz University of Technology, in 2012, and is currently PhD student at Shiraz University of Technology. He is Director of the Civil Department of Islamic Azad University of Lordegan Center, Shahrekord, Iran. 